\title{
How important are mangroves as a carbon source for decapod crustacean larvae in a tropical estuary?
}

\author{
Ralf Schwamborn $^{1, *}$, Werner Ekau ${ }^{1}$, Maren Voss ${ }^{2}$, Ulrich Saint-Paul ${ }^{1}$ \\ ${ }^{1}$ Center for Tropical Marine Ecology (ZMT), Fahrenheitstraße 6, 28359 Bremen, Germany \\ ${ }^{2}$ Baltic Sea Research Institute (IOW), Seestraße 15, 18119 Rostock-Warnemünde, Germany
}

\begin{abstract}
In order to evaluate the importance of mangrove leaf detritus as a food source for decapod crustacean larvae, stable isotopes $\left(\delta^{13} \mathrm{C}\right.$ and $\left.\delta^{15} \mathrm{~N}\right)$ were measured in the tissue of these larvae and other selected organisms. Decapod crustacean larvae and planktonic adult decapods, Lucifer faxoni and Acetes americanus, were sampled in the Itamaracá estuarine system, Brazil. For comparison with stable isotope values in the estuary, plankton and POM samples were also taken on the adjacent continental shelf. In the Itamaracá estuarine system, $\delta^{13} \mathrm{C}$ of decapod larvae and the holoplanktonic decapods $L$. faxoni and A. americanus ranged from about -17 to $-23 \%$ (mean: $-19.8 \pm 1.5 \%$ ). This indicates that the contribution of mangrove carbon $\left(\delta^{13} \mathrm{C}:-26.8 \%\right.$ ) to larval nutrition was generally negligible. Among decapod larvae, porcellanid zoeae showed relatively low $\delta^{13} \mathrm{C}$ values, while penaeid shrimp postlarvae showed the highest $\delta^{13} \mathrm{C}$. Porcellanid zoeae were thus the only decapod larvae with a considerable percentage (13 to $40 \%$ ) of mangrove carbon in their tissue. However, these low values may also be due to a negative isotope shift that occurs during embryogenesis. Feeding experiments with zoeae of Petrolisthes armatus (Anomura: Porcellanidae) and Sesarma rectum (Brachyura: Grapsidae) showed assimilatory shifts of up to $1.0 \pm 0.2 \%$ for ${ }^{13} \mathrm{C}$ and up to $1.4 \pm 0.6 \%$ for ${ }^{15} \mathrm{~N}$. Analysis of embryonic isotope fractionation for 5 decapod crustacean species, P. armatus, S. rectum, Aratus pisonii, Uca thayeri, and U. maracoani, showed that larval tissue was ${ }^{13} \mathrm{C}$-depleted by up to $3.8 \%$ and ${ }^{15} \mathrm{~N}$-depleted by up to $2.3 \%$ in relation to parental tissue.
\end{abstract}

KEY WORDS: Decapod crustacean larvae - Stable isotopes - Mangrove estuaries - Detritus · Food webs Resale or republication not permitted without written consent of the publisher

\section{INTRODUCTION}

The fate of organic detritus in mangrove ecosystems has been the focus of several biological and geochemical studies (see reviews in Robertson et al. 1992, Lee 1995, Schwamborn \& Saint-Paul 1996, Lee 1999). It is generally believed that food webs in mangrove forests and adjacent aquatic ecosystems are closely linked by several interaction processes. Three such processes that have been amply studied are: (1) trophic coupling through detritus food chains (Odum 1971, McKinnon \&

\footnotetext{
*Present address: Departamento de Oceanografia, Universidade Federal de Pernambuco, 50 730-540 Recife, Brazil. E-mail: rs@npd.ufpe.br
}

Klumpp 1998), (2) mass production of planktonic larvae by mangrove invertebrates, which contribute to pelagic food webs (Robertson et al. 1988, Schwamborn et al. 1999a), and (3) utilisation of floating mangrove leaves as substrate for aquatic organisms, especially fish and decapod crustacean larvae (Wehrtmann \& Dittel 1990, Schwamborn \& Bonecker 1996).

Larvae of mangrove invertebrates are very common in tropical estuarine zooplankton and often dominate certain size fractions (Robertson et al. 1988, Schwamborn et al. 1999a). The input of decapod crustacean larvae into the pelagic realm can be a very important food source for planktivorous fishes (Morgan 1990). The energy transfer through predation on planktonic larvae may be one of the main pathways of benthopelagic coupling in mangrove estuaries. Therefore, 
the export of decapod crustacean larvae from mangrove estuaries to adjacent shelf areas is of direct benefit for marine pelagic food webs (Schwamborn et al. 1999a).

Furthermore, many authors have considered trophic coupling through detritus food chains to be the most important pathway of energy transfer from mangrove ecosystems to adjacent water bodies (Odum 1971, Odum \& Heald 1972, Wolff et al. 1998, 2000). Confirming the existence of this pathway, experimental and field evidence has been presented for ingestion and assimilation of vascular plant detritus by zooplankton (Roman \& Rublee 1981, Roman 1984, DeMott 1988, Stoner \& Zimmerman 1988, Posch \& Arndt 1996, McKinnon \& Klumpp 1998) and juvenile decapod crustaceans (Rodelli et al. 1984, Loneragan et al. 1997, Fantle et al. 1999, Dittel et al. 2000, Schwamborn \& Criales 2000), although for most organisms studied, live food was more important than detritus.

Mangrove estuaries are used as nursery areas by many commercially important shrimp species. The immigration of shrimp postlarvae has been attributed to the abundant food supply in comparison to adjacent marine areas (Robertson 1991, Robertson \& Blaber 1992). Microalgae, mangrove leaf detritus, and zooplankton are the major food resources available to decapod larvae in mangrove estuaries. There are few studies on the diet of tropical decapod larvae and postlarvae (Briones 1988). The investigation of diets of decapod larvae based on microscopic examination may tend to underestimate more fragile food items, since the food is strongly triturated during ingestion. Filamentous algae and detritus may be underestimated by visual counting because of the absence of hard structures. Rapid digestion is an additional problem for stomach content analysis in planktonic decapods (Lee et al. 1992).

Planktonic brachyuran larvae have generally been assumed to prey on zooplankton (McConaugha 1985, Harms \& Seeger 1989, Welch \& Epifanio 1995). This concept is based on laboratory experiments, in which diatom-fed brachyuran zoeae display higher mortalities, delayed development, slower growth, lower carbon ingestion and reduced nucleotide content in relation to Artemia-fed controls (Harms \& Seeger 1989, Harms et al. 1991, Harms 1992). Because of its effectiveness in promoting growth in various species, and because of the ease of standardisation (in regard to amount of food offered, size and biochemical composition), Artemia sp. nauplii have been used as standard food source for feeding experiments in this and several other studies (DeNiro \& Epstein 1978, Fry \& Arnold 1982, Fantle et al. 1999, Gorokhova \& Hansson 1999). Conversely, field studies have shown that diatoms are a major component of the natural diet of brachyuran larvae (Meyer-Harms \& Harms 1993, Harms et al. 1994). These field studies showed that although diatoms are not suitable as a sole food source for most species, they may be at least an additional food source under natural conditions.

The present study is the first attempt to quantify the contribution of mangrove carbon to the diet of a tropical decapod larval community by stable isotope analysis. For the assessment of food sources of decapod larvae by $\delta^{13} \mathrm{C}$ measurements, only advanced stages, such as postlarvae and megalopae, are suitable, since early stages probably contain large amounts of embryonic carbon derived from adult nutrition.

For the proper interpretation of stable isotope data for any given organism, it is necessary to know the metabolic shift between the organism's tissue and its food, that is caused by assimilation and respiration (DeNiro \& Epstein 1978, Teeri \& Schoeller 1979). Although several experiments for the determination of this shift have been conducted with postlarval and juvenile shrimps and crabs (Fry \& Arnold 1982, Gleason 1986, Dittel et al. 1997, Fantle et al. 1999), no such data are available for early stages, such as penaeid, brachyuran, or porcellanid zoeae. Additionally, this isotopic shift is only reflected in the animal after a certain time, which is determined by the growth and turnover rates of the tissue investigated (Fry \& Arnold 1982).

Furthermore, for an interpretation of stable isotope values of early larval stages collected in the field, it is most valuable to know whether there is an isotope shift between parental and embryonic tissue during embryogenesis. No data are available on the relationship between isotope values in parental and embryonic or early larval tissue. If there is a constant or negligible isotopic shift during embryogenesis, stable isotope measurements of recently hatched larvae collected in the field may allow a time-integrated, spatially averaged assessment of the primary food sources that are assimilated by parental crustacean populations and further transferred to pelagic food webs in the form of larval biomass.

\section{MATERIALS AND METHODS}

Study area. The Itamaracá estuarine system is located in northeastern Brazil, about $55 \mathrm{~km}$ to the north of the city of Recife (Fig. 1). It consists of 5 small rivers draining into a U-shaped channel of $20 \mathrm{~km}$ length with 2 connections to the Atlantic Ocean. Salinity in the estuary varies from about $15 \%$ in the rainy season to marine or slightly hypersaline conditions in the dry season. Water temperature ranges between approximately 28 and $30^{\circ} \mathrm{C}$ (Medeiros \& Kjerfve 1993, Schwamborn 1997). The system sustains $36 \mathrm{~km}^{2}$ of 
mangrove forests, dominated by Avicennia schaueriana, Laguncularia racemosa and Rhizophora mangle (Medeiros \& Kjerfve 1993). About 10 penaeoid, 19 caridean and 47 brachyuran species have been reported from the estuary (Coelho \& Ramos-Porto 1995). Mesozooplankton in the estuary and on the adjacent shelf is dominated by decapod crustacean larvae and copepods (Schwamborn 1997, Schwamborn et al. 1999a). Towards the shelf, sandstone reefs delimit the estuarine system. Beyond the reefs, fragments of calcareous algae (Halimeda sp.) form a characteristic gravel bottom along the continental shelf (Kempf et al. 1970).

Sampling. Decapod crustacean larvae and holoplanktonic adult decapods (Lucifer faxoni and Acetes americanus) were sampled in the Itamaracá estuarine system from August 1993 to May 1996. Samples of several other compartments of the estuarine ecosystem were taken for comparison with stable isotope values

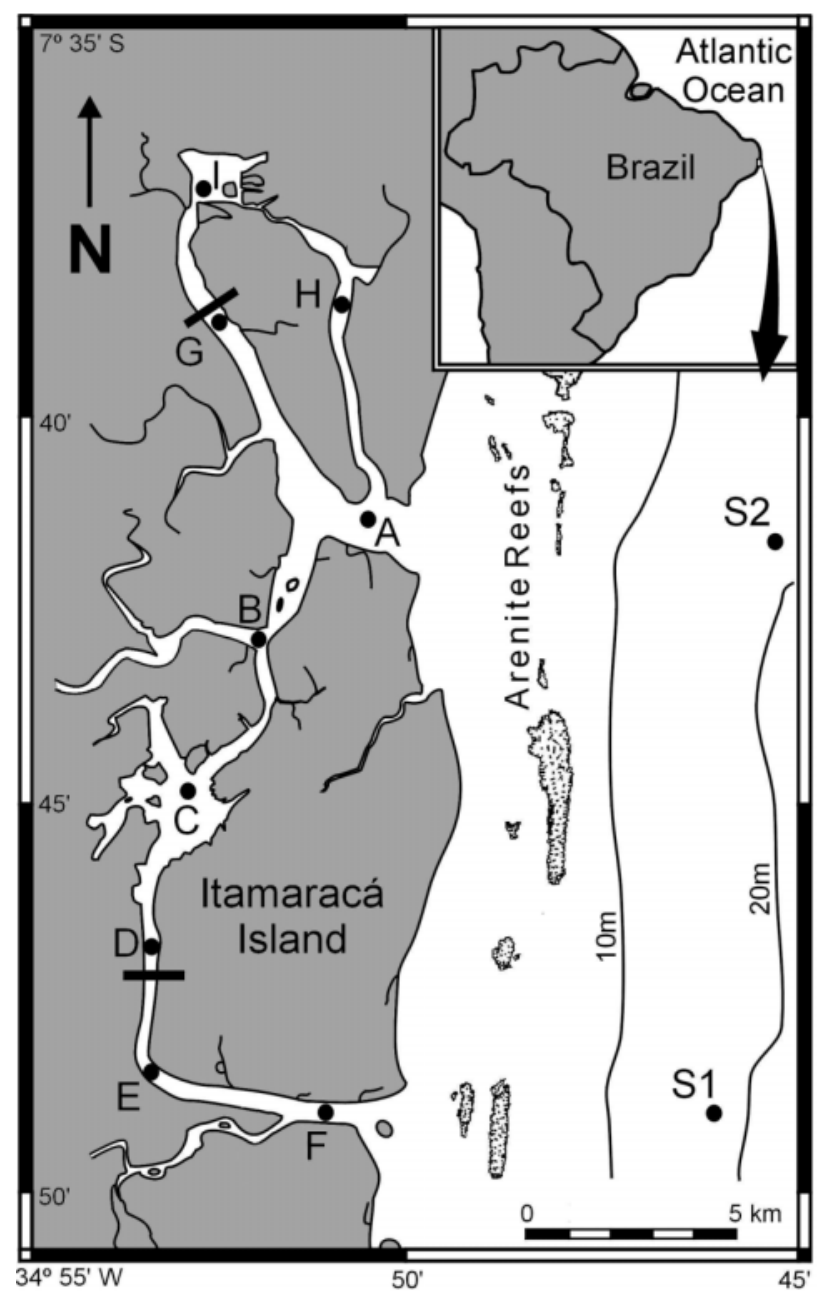

Fig. 1. Station map of the Itamaracá estuarine system and the adjacent continental shelf. A to I: estuarine stations; S1, S2: continental shelf stations of decapod larvae. These compartments were: mangrove leaves, sediments, suspended particulate organic matter $(\mathrm{POM})$, coarse vascular plant detritus $(>300 \mu \mathrm{m})$, and estuarine copepods. For comparison with zooplankton, and with values of macrofauna from other regions, samples of mangrove oysters Crassostrea rhizophorae, adults of the penaeid shrimp species Litopenaeus schmitti and Farfantepenaeus subtilis, and adults of the sardine Opisthonema oglinum were also measured. Sampling was performed at 9 stations (Stns A to I) from the hydrographic centre of the estuary (Stn C) to the estuarine inlets (Stns A and F) (Fig. 1).

Leaves of 3 mangrove species (Avicennia schaueriana, Laguncularia racemosa and Rhizophora mangle) were collected at 2 different stages of senescence and decomposition: fresh green leaves, and loose brown leaves found between branches. For each species and senescence stage, at least 30 leaves were collected. A natural mixture of mangrove leaves drifting on the surface of estuarine waters was collected 3 times (approx. 80 leaves per sample) with a small hand net. Mangrove leaf samples were immediately washed free of adherent mud and debris and frozen until further analysis. Particulate organic matter from the surface water was collected with a van Dohrn sampler at Stns A and C, on 4 dates, always at low tide. Later, $500 \mathrm{ml}$ of these water samples were filtered through pre-combusted GF/C filters (approx. $0.5 \mu \mathrm{m}$ pore size). Surface sediments were collected with a van Veen grab at Stations C, D, F and I to compare areas with different degrees of mangrove influence. To obtain decapod larvae and copepods, 16 plankton net $(300 \mu \mathrm{m}$ mesh size, $60 \mathrm{~cm}$ diameter) hauls were performed at 9 stations (Stns A to I) from 1993 to 1995 (Fig. 1). All plankton samples were kept on ice after the hauls and sorted within $12 \mathrm{~h}$. The taxonomic composition of the zooplankton was determined for each sample based on subsamples of 0.01 to $0.1 \%$ volume. Fragments of vascular plant detritus found in plankton net samples were sorted out with a clean forceps until 100 fragments had been collected, rinsed and analysed separately. The most abundant decapod crustacean larvae, postlarvae and adult planktonic decapods (Lucifer faxoni and Acetes americanus) were identified under a binocular microscope, sorted, cleaned and rinsed before storage at $-20^{\circ} \mathrm{C}$. A total of 515 individuals of estuarine decapod crustaceans were identified, cleaned and analysed.

To obtain additional samples from an area without mangrove detritus, plankton and POM were also sampled at 2 stations on the adjacent continental shelf (Stns S1 and S2). These shelf samples were taken in March 1995 on board RV 'Victor Hensen'. Shelf stations were located $>5 \mathrm{~km}$ off the maximum extent of the estuarine plume (Fig. 1). Plankton net mesh size and sampling of POM were analogous to sampling 
methods used in the estuary. At each shelf station, 1 zooplankton sample and 2 POM samples were taken. All samples were frozen at $-70^{\circ} \mathrm{C}$ on board.

In the laboratory, decapod larvae and other dominant taxa were identified and sorted out of plankton samples prior to measurement. We measured 12 samples (4 POM and 8 zooplankton samples) obtained at shelf stations, and 58 samples (10 mangrove leaf, 5 coarse detritus, 8 POM, 6 sediment, 4 macrofauna and 25 zooplankton samples) from the estuary.

Determination of assimilatory and embryonic shifts. To determine the difference between the stable isotope $\left({ }^{13} \mathrm{C}\right.$ and $\left.{ }^{15} \mathrm{~N}\right)$ composition of decapod crustacean larvae and their food, feeding experiments were conducted in the laboratory with a single food source. Ovigerous females of Petrolisthes armatus (Anomura: Porcellanidae) and Sesarma rectum (Brachyura: Grapsidae) were collected at Itamaracá Island, and kept in the laboratory under in situ conditions (salinity: $25 \%$, temperature: 27 to $29^{\circ} \mathrm{C}$ ). Immediately after hatching, zoeae were fed nauplii of Artemia sp. for up to $15 \mathrm{~d}$. The zoeae were then subsampled every $2 \mathrm{~d}$. For each species, the assimilatory shift was calculated as the difference between the stable isotope values of the last larval stages obtained in the laboratory and the stable isotope values of the larval food. Before sampling, the larvae were allowed to defecate for $2 \mathrm{~h}$, thus avoiding the addition of stomach content to the samples.

To determine the isotopic shift during embryogenesis, stable isotope values $\left(\delta^{13} \mathrm{C}\right.$ and $\left.\delta^{15} \mathrm{~N}\right)$ of parental and larval tissue were compared for 5 decapod crustacean species that occur at IES, Petrolisthus armatus, Sesarma rectum, Aratus pisonii, Uca thayeri, and U. maracoani. Ovigerous females of these species were captured at Itamaracá Island and kept in the laboratory under in situ conditions for up to $5 \mathrm{~d}$. Immediately after hatching, 20 to 30 larvae were collected per female, rinsed with distilled water and frozen at $-20^{\circ} \mathrm{C}$ until further analysis. The embryonic isotope shift was later calculated as the difference between the stable isotope values of whole recently hatched zoeae and pereiopod muscle tissue of the corresponding parental females.

Isotope analysis. Each stable isotope sample of decapod zoeae consisted of 20 to 30 individuals. For the more advanced development stages (megalopae, postlarvae and juveniles), 5 to 10 individuals were taken for each sample. All organisms were individually cleaned from adherent detritus under a stereomicroscope and washed repeatedly with distilled water before storage at $-20^{\circ} \mathrm{C}$. Before measurement, all samples were rinsed with distilled water, dried at $65^{\circ} \mathrm{C}$ for at least $24 \mathrm{~h}$, and homogenised. Subsamples of 0.7 to $1.8 \mathrm{mg}$ dry weight were acidified with $\mathrm{HCl}$ and dried. Finally, the carbonate-free subsamples were combusted and analysed using a gas isotope ratio mass spectrometer. Samples were combusted in a CarloErba 1108 CN-Analyser connected to a Finnigan MAT mass spectrometer (Model Delta-S) by a split interface. Gas samples were measured under continuous helium flow, with alternating measurements of 5 samples and 1 standard. The ratios of heavy to light isotope are expressed using the standard $\delta$ notation (Craig 1957), where positive values indicate enrichment and negative values indicate depletion of the heavy isotope relative to a standard. For both gases $\left(\mathrm{CO}_{2}\right.$ and $\left.\mathrm{N}_{2}\right)$, gas tanks were used as laboratory standards, which were calibrated against NBS-Standards 18 and 20 for $\delta^{13} \mathrm{C}$ and IAEA Standards N1, N2, and N3 for $\delta^{15} \mathrm{~N}$. Measurement precision was calculated from the difference between replicate values of a peptone standard (Merck), that was measured after every fifth sample. Precision was $0.15 \%$ o for ${ }^{13} \mathrm{C}$, and $0.2 \%$ for ${ }^{15} \mathrm{~N}$. $\delta^{13} \mathrm{C}$ values are given as per mil deviation from PDB limestone (Craig 1957), $\delta^{15} \mathrm{~N}$ values as per mil deviation from atmospheric nitrogen (Mariotti 1983).

The contribution of mangrove carbon to given compartments was assessed by inserting the measured $\delta^{13} \mathrm{C}$ values into the following mixing equation:

$M_{i}(\%)=100 \times\left(\delta^{13} \mathrm{C}_{i}-F_{i}-\delta^{13} \mathrm{C}_{\mathrm{PP}}\right) /\left(\delta^{13} \mathrm{C}_{\mathrm{M}}-\delta^{13} \mathrm{C}_{\mathrm{PP}}\right)$ where $M_{i}$ is the percent contribution of mangrove carbon to organic carbon in Compartment i. $\delta^{13} \mathrm{C}_{\mathrm{PP}}$ and $\delta^{13} \mathrm{C}_{\mathrm{M}}$ are the $\delta^{13} \mathrm{C}$ values of phytoplankton and mangrove leaves, respectively. $F_{i}$ is the fractionation (enrichment due to assimilation and respiration) of ${ }^{13} \mathrm{C}$ in Compartment $i$, which is assumed to be between 0 and $1.5 \%$ for consumers, and 0 for sediments and POM. This mixing equation calculates the contribution of mangrove carbon assuming that only 2 sources are contributing to the isotope signature of the respective compartment. To estimate the relative contributions of mangrove leaves and phytoplankton to given compartments, $\delta^{13} \mathrm{C}$ values of floating mangrove leaves were used for mangrove carbon, and previously published $\delta^{13} \mathrm{C}$ values for phytoplankton carbon $(-21.3 \pm 1.1 \%$, see Schwamborn 1997 and references cited therein). Student's $t$-tests (Zar 1996) were performed at $\alpha=0.05$ to compare pairs of stable isotope values (e.g. $\delta^{13} \mathrm{C}$ values of estuarine and marine particulate organic matter).

\section{RESULTS}

\section{Mangrove leaves and particulate organic matter}

Mangrove leaves of different species and at different senescence stages showed little variation in $\delta^{13} \mathrm{C}$, with values between -26.8 and $-25.5 \%$ (Table 1 ). The $\delta^{13} \mathrm{C}$ of drifting mangrove leaves agreed well with the value measured for a mixture of mangrove leaves from dif- 


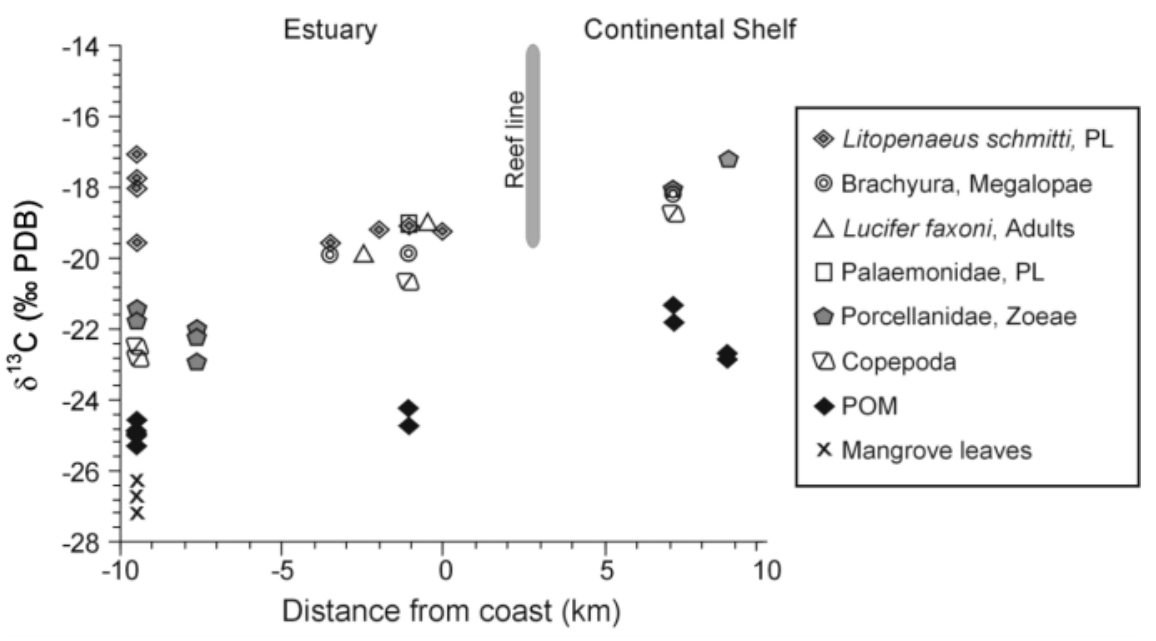

Fig. 2. Stable carbon isotope ratios $\left(\delta^{13} \mathrm{C}\right)$ of zooplankton, particulate organic matter (POM), and drifting mangrove leaves in the Itamaracá estuarine system and adjacent shelf stations. Negative distance values indicate stations inside the estuary. PL: postlarvae

ferent species, weighted by species biomass in the study area (Table 1).

$\delta^{13} \mathrm{C}$ values of coarse mangrove leaf detritus, POM, and sediments in the estuary showed very similar values, around $-25 \%$ (Table 1$)$. Mangrove leaves were the main carbon source for estuarine POM (average: $66 \pm 7 \%$ mangrove carbon) and estuarine sediments (average: $69 \pm 9 \%$ mangrove carbon). Sediments at the southern inlet (Stn F) were considerably ${ }^{13} \mathrm{C}$ -

Table 1. Stable isotope ratios $\left(\delta^{13} \mathrm{C}\right.$ and $\left.\delta^{15} \mathrm{~N}\right)$ of mangrove leaves, coarse vascular plant detritus $(>300 \mu \mathrm{m})$, estuarine particulate organic matter (POM), and sediments collected from the Itamaracá estuarine system, Brazil. Number of measured samples (n), mean isotope ratios and standard deviation are given. $\delta^{13} \mathrm{C}$ is given as \%o $\mathrm{PDB}$, $\delta^{15} \mathrm{~N}$ as \%o atmospheric nitrogen. Percent mangrove contributions $M_{\mathrm{i}}$ to organic carbon were calculated from mixing equations employing the values of $-26.8 \%$ PDB and $-21.3 \%$ PDB for mangrove and phytoplankton carbon, respectively

\begin{tabular}{|c|c|c|c|c|c|}
\hline \multirow{2}{*}{$\begin{array}{l}\text { Compartment } \\
\text { Mangrove leaves }\end{array}$} & \multicolumn{2}{|c|}{$\begin{array}{c}\delta^{13} \mathrm{C}\left(\%{ }^{\circ} \mathrm{PDB}\right) \\
(\mathrm{n}) \quad \text { mean } \pm \mathrm{SD}\end{array}$} & \multicolumn{2}{|c|}{$\begin{array}{l}\delta^{15} \mathrm{~N}(\% \text { atm }) \\
(\mathrm{n}) \text { mean } \pm \mathrm{SD}\end{array}$} & $\begin{array}{l}M_{\mathrm{i}} \\
(\%)\end{array}$ \\
\hline & & & & & \\
\hline Drifting mangrove leaves & (3) & $-26.8 \pm 0.4$ & & & 100 \\
\hline Avicennia schaueriana, green leaves & 1 & -26.4 & & & \\
\hline Avicennia schaueriana, brown leaves & 1 & -25.5 & & & \\
\hline Laguncularia racemosa, green leaves & 1 & -25.6 & & & \\
\hline Laguncularia racemosa, brown leaves & 1 & -25.6 & & & \\
\hline Rhizophora mangle, green leaves & 1 & -26.8 & & & \\
\hline Rhizophora mangle, brown leaves & 1 & -26.5 & & & \\
\hline Green mangrove leaves, mixture & 1 & -26.6 & (1) & 4.4 & \\
\hline Coarse detritus $(>300 \mu \mathrm{m})$ & 5 & $-25.1 \pm 0.8$ & (3) & $4.7 \pm 1.4$ & \\
\hline Estuarine POM & 8 & $-24.9 \pm 0.4$ & $(4)$ & $3.8 \pm 1.7$ & $66 \pm 7$ \\
\hline \multicolumn{6}{|l|}{ Sediments } \\
\hline Estuary & (4) & $-25.1 \pm 0.5$ & & & $69 \pm 9$ \\
\hline Estuarine inlet & (2) & $-22.1 \pm 0.2$ & & & $15 \pm 3$ \\
\hline
\end{tabular}

enriched compared to inner estuarine sediments (Table 1). Shelf POM $\left(\delta^{13} \mathrm{C}:-22.2 \pm 0.71, \mathrm{n}=4\right)$ was significantly $(p=0.002){ }^{13} \mathrm{C}$-enriched in relation to estuarine POM $\left(\delta^{13} \mathrm{C}\right.$ : $-24.7 \pm 0.38, \mathrm{n}=4$ ) (Fig. 2). $\delta^{15} \mathrm{~N}$ values of mangrove leaves, mangrove leaf detritus, and estuarine POM were very similar, ranging between 3.8 and $4.7 \%$ o (Table 1).

\section{Decapod larvae and copepods}

$\delta^{13} \mathrm{C}$ values measured for estuarine decapod larvae and holoplanktonic decapods (Lucifer faxoni and Acetes americanus) covered a wide span of values, from -23 to $-17 \%$, including the assumed phytoplankton value of $-21.3 \%$ (Fig. 2). All decapod crustaceans were considerably ${ }^{13} \mathrm{C}$-enriched in relation to mangrove leaves, mangrove detritus, estuarine POM and estuarine sediments. The mean $\delta^{13} \mathrm{C}$ of decapod larvae, postlarvae and planktonic adults was $-19.8 \pm 1.5 \%$. Applying fractionation $(F)$ values between 0 and $1.5 \%$, this average $\delta^{13} \mathrm{C}$ value corresponds to a contribution of 0 to $8 \%$ mangrove carbon. Among estuarine decapod larvae, porcellanid zoeae (dominated by Petrolisthes armatus) showed to be most ${ }^{13} \mathrm{C}$-depleted, while penaeid shrimp postlarvae were the most ${ }^{13} \mathrm{C}$-enriched estuarine decapods (Fig. 3). Porcellanid zoeae were thus the only decapods to show a considerable percentage (13 to $40 \%$ ) of mangrove carbon (Table 2). Conversely, the mangrove contribution to brachyuran (mainly Zoeae I of Uca sp.) and alpheid zoeae was negligible (Table 2).

Samples of porcellanid zoeae, copepods and POM in the estuary tended to be ${ }^{13} \mathrm{C}$-depleted in comparison to corresponding shelf samples (Fig. 2). In contrast, postlarval stages (e.g. shrimp postlarvae and brachyuran megalopae) displayed $\delta^{13} \mathrm{C}$ values which were in the range of values found for shelf zooplankton (see Figs. 2 \& 3). Postlarvae of Litopenaeus schmitti caught in the inner estuary were on average ${ }^{13} \mathrm{C}$-enriched by $1.2 \%$ in comparison to individuals caught 


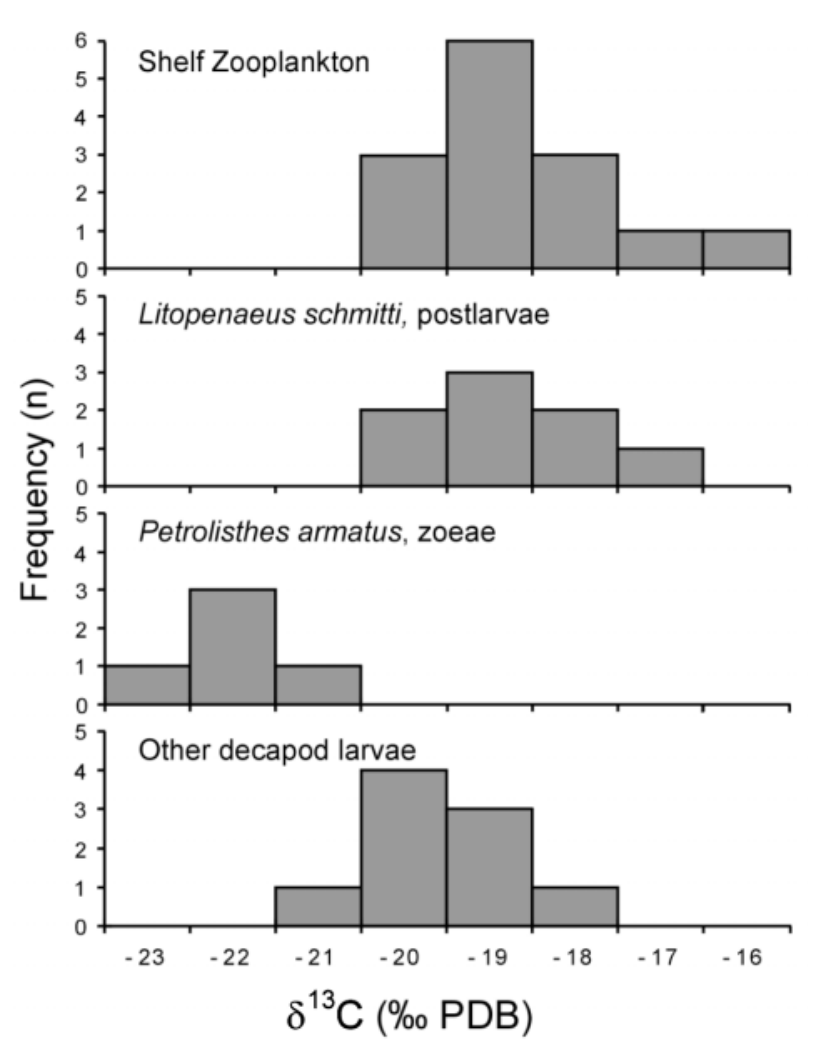

Fig. 3. Frequency distribution of zooplankton $\delta^{13} \mathrm{C}$ values measured at the Itamaracá estuarine system and at the northeast Brazilian continental shelf. Shelf data are from Schwamborn et al. (1999b)

near the inlets (Fig. 1). However, this difference was marginally not significant at $\mathrm{p}=0.056$ (Zar 1996).

Estuarine decapod postlarvae $\left(\delta^{13} \mathrm{C}:-19.02 \pm 0.89 \%\right.$, $\mathrm{n}=10)$ were significantly $(\mathrm{p}<0.0001){ }^{13} \mathrm{C}$-enriched by $2.6 \%$ compared to estuarine copepods (dominated by Acartia lilljeborgi). The mangrove carbon content of estuarine postlarval and pelagic adult decapods, as calculated from mixing equations, was negligible (Table 2).

$\delta^{15} \mathrm{~N}$ values of decapod larvae and copepods in the estuary were very similar (6.2 to $7.7 \%$ ), and were significantly $(p=0.014){ }^{15} \mathrm{~N}$-enriched compared to estuarine POM $(3.8 \pm 1.7 \%)$. $\delta^{15} \mathrm{~N}$ values of estuarine POM were not significantly different from shelf POM $(3.5 \pm 1.2 \%)$. There was also no significant difference between zooplankton $\delta^{15} \mathrm{~N}$ in the estuary $(6.8 \pm 0.71 \%)$ and zooplankton on the adjacent shelf $(5.96 \pm 0.96 \%)$.

\section{Isotope shifts}

Stable isotope ratios of laboratory-fed decapod larvae displayed rapid changes during the first few days, reaching a plateau of constant values after 6 to $9 \mathrm{~d}$

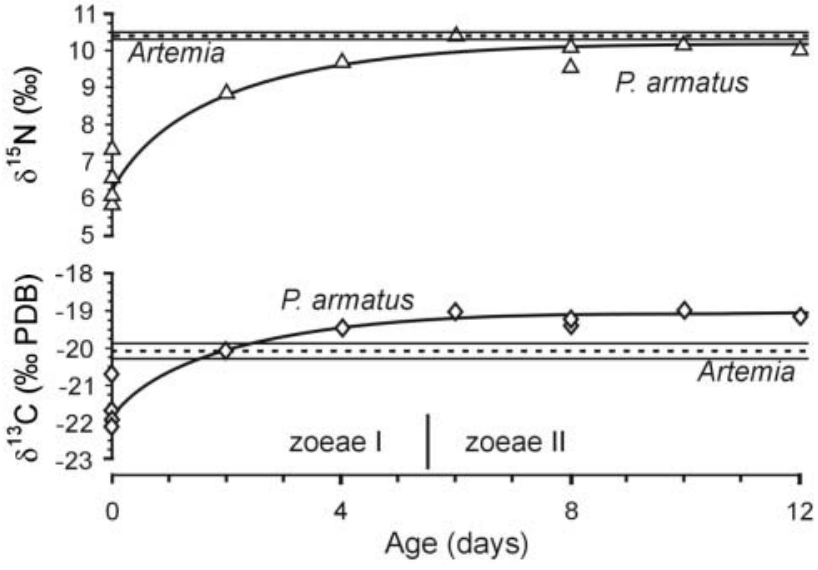

Fig. 4. Petrolisthes armatus zoeae (Decapoda: Anomura: Porcellanidae). Stable isotope ratios $\left(\delta^{13} \mathrm{C}\right.$ and $\left.\delta^{15} \mathrm{~N}\right)$ during feeding experiments. Artemia: standard deviation and average (dashed line) of stable isotope values of recently ecloded

Artemia sp. (Salt Lake City, USA) nauplii used as food

(Figs. 4 \& 5). C/N ratios were between 4.5 and 5.7 during feeding experiments. The dry weight of Petrolisthes armatus zoeae fed Artemia sp. nauplii was about 6 -fold $12 \mathrm{~d}$ after hatching. At the end of the experiment, $\delta^{15} \mathrm{~N}$ of $P$. armatus zoeae $(10.2 \pm 0.3 \%, \mathrm{n}=4)$ was not significantly different from that of Artemia sp. $(10.4 \pm 0.2 \%$, $\mathrm{n}=3$ ) (Fig. 4). However, P. armatus zoeae were ${ }^{13} \mathrm{C}$ enriched by $1.0 \pm 0.2 \%$ in comparison to food carbon (P. armatus: $-19.1 \pm 0.2 \%, \mathrm{n}=4$; food: $-20.1 \pm 0.4 \%$, $\mathrm{n}=3$ ). In contrast, the assimilatory shift of Sesarma rectum was zero for $\delta^{13} \mathrm{C}$ ( $S$. rectum: $-11.6 \pm 0.5 \%, \mathrm{n}=3$; food: $-11.1 \pm 0.4 \%, \mathrm{n}=3$ ) (Fig. 5). For $\delta^{15} \mathrm{~N}, S$. rectum larvae displayed an assimilatory shift of $1.4 \pm 0.6 \%$ (S. rectum: $8.0 \pm 0.2 \%, \mathrm{n}=3$; food: $6.5 \pm 0.2 \%, \mathrm{n}=3$ ).

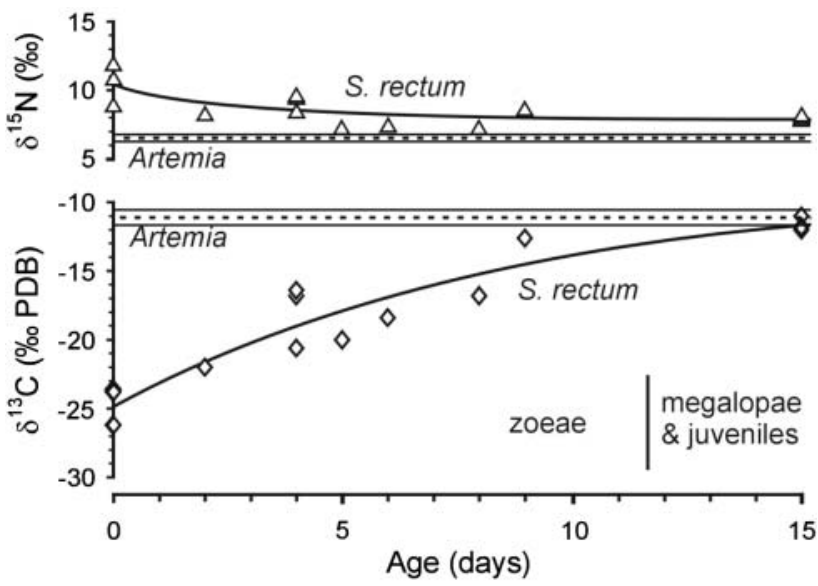

Fig. 5. Sesarma rectum larvae (Decapoda: Brachyura: Grapsidae). Stable isotope ratios $\left(\delta^{13} \mathrm{C}\right.$ and $\left.\delta^{15} \mathrm{~N}\right)$ during feeding experiments. Artemia: standard deviation and average (dashed line) of stable isotope values of recently ecloded Artemia sp. (Macau, Brazil) nauplii used as food 
Table 2. Stable carbon isotope ratios and estimated percent mangrove contributions to organic carbon of aquatic organisms in the Itamaracá estuarine system, Brazil. Percent mangrove contributions $\left(M_{\mathrm{i}}\right)$ to organic carbon were calculated from mixing equations employing the $\delta^{13} \mathrm{C}$ values of $-26.8 \%$ PDB and $-21.3 \%$ PDB for mangrove and phytoplankton carbon, respectively. Minimum mangrove contributions were calculated using raw $\delta^{13} \mathrm{C}$ values, maximum contributions were estimated by subtracting $1.5 \%$ from actual $\delta^{13} \mathrm{C}$ values

\begin{tabular}{|c|c|c|c|c|c|}
\hline \multirow[t]{2}{*}{ Compartment } & \multicolumn{2}{|c|}{ Number of } & \multirow{2}{*}{$\begin{array}{c}\delta^{13} \mathrm{C} \\
(\% \text { PDB }) \\
\text { mean } \pm \mathrm{SD}\end{array}$} & \multicolumn{2}{|c|}{$M_{\mathrm{i}}(\%)$} \\
\hline & $\begin{array}{l}\text { Sam- } \\
\text { ples }\end{array}$ & $\begin{array}{l}\text { Indivi- } \\
\text { duals }\end{array}$ & & $\begin{array}{l}\text { Min } \\
(F=0)\end{array}$ & $\begin{array}{c}\operatorname{Max} \\
(F=1.5 \% \text { o })\end{array}$ \\
\hline \multicolumn{6}{|l|}{ Decapod postlarvae } \\
\hline $\begin{array}{l}\text { Litopenaeus schmitti, } \\
\text { postlarvae }\end{array}$ & 8 & 27 & $-18.7 \pm 0.9$ & 0 & 0 \\
\hline Palaemonidae, postlarvae & 1 & 8 & -19.0 & 0 & 0 \\
\hline Brachyura, megalopae & 2 & 11 & $-19.9,-19.9$ & 0 & 0 \\
\hline \multicolumn{6}{|l|}{ Adult planktonic decapods } \\
\hline Lucifer faxoni, adults & 2 & 158 & $-19.0,-19.9$ & 0 & 0 \\
\hline Acetes americanus, adults & 1 & 5 & -18.0 & 0 & 0 \\
\hline \multicolumn{6}{|l|}{ Decapod zoeae } \\
\hline Porcellanidae, zoeae & 5 & 131 & $-22.0 \pm 0.6$ & $13 \pm 11$ & $40 \pm 11$ \\
\hline Brachyura, zoeae & 2 & 150 & $-18.7,-20.3$ & 0 & 0 to 9 \\
\hline Alpheidae, Zoeae II to IV & 1 & 25 & -20.6 & 0 & 15 \\
\hline $\begin{array}{l}\text { Estuarine copepods } \\
\qquad(>80 \% \text { Acartia lilljeborgi) }\end{array}$ & 3 & 900 & $-22.0 \pm 0.3$ & $13 \pm 5$ & $40 \pm 5$ \\
\hline \multicolumn{6}{|l|}{ Estuarine macrofauna } \\
\hline $\begin{array}{l}\text { Crassostrea rhizophorae, } \\
\text { adults }\end{array}$ & 1 & 24 & -23.2 & 35 & 62 \\
\hline \multicolumn{6}{|l|}{ White shrimp } \\
\hline $\begin{array}{l}\text { Farfantepenaeus schmitti, } \\
\text { adults }\end{array}$ & 1 & 10 & -18.2 & 0 & 0 \\
\hline \multicolumn{6}{|l|}{ Pink shrimp } \\
\hline $\begin{array}{l}\text { Litopenaeus subtilis, } \\
\text { adults }\end{array}$ & 1 & 10 & -19.7 & 0 & 0 \\
\hline \multicolumn{6}{|l|}{ Sardine } \\
\hline $\begin{array}{l}\text { Opisthonema oglinum, } \\
\text { adults }\end{array}$ & 1 & 10 & -20.2 & 0 & 7 \\
\hline
\end{tabular}

Table 3. Stable isotope ratios $\left(\delta^{13} \mathrm{C}\right.$ and $\left.\delta^{15} \mathrm{~N}\right)$ and metabolic isotope shift during embryogenesis for 5 decapod crustacean species. Embryonic shift was calculated as the difference between stable isotope values of adult tissue and values of recently ecloded zoeae

\begin{tabular}{|c|c|c|c|c|}
\hline $\begin{array}{l}\text { Species, stage } \\
\text { (n samples) }\end{array}$ & $\begin{array}{cr}\delta^{13} \mathrm{C} & \mathrm{En} \\
(\% \text { PDB }) & \mathrm{s}\end{array}$ & $\begin{array}{l}\text { Embryonic } \\
\text { shift }(\%)\end{array}$ & $\begin{array}{l}\delta^{13} \mathrm{~N} \\
(\%)\end{array}$ & $\begin{array}{l}\text { Embryonic } \\
\text { shift }(\%)\end{array}$ \\
\hline $\begin{array}{r}\text { Petrolisthes armatus adults (1) } \\
\text { zoeae (4) }\end{array}$ & $\begin{array}{l}-20.1 \\
-21.6 \pm 0.6\end{array}$ & $.6-1.5$ & $\begin{array}{l}7.5 \\
6.4 \pm 0.7\end{array}$ & -1.1 \\
\hline $\begin{array}{ll}\text { Sesarma rectum } & \text { adults (1) } \\
& \text { zoeae (1) }\end{array}$ & $\begin{array}{l}-21.3 \\
-23.6\end{array}$ & -2.3 & $\begin{array}{l}14.2 \\
11.9\end{array}$ & -2.3 \\
\hline $\begin{array}{l}\text { adults (1) } \\
\text { zoeae (1) }\end{array}$ & $\begin{array}{l}-22.6 \\
-26.4\end{array}$ & -3.8 & $\begin{array}{l}6.1 \\
4.5\end{array}$ & -1.6 \\
\hline $\begin{array}{l}\text { adults (1) } \\
\text { zoeae (1) }\end{array}$ & $\begin{array}{l}-13.6^{\mathrm{a}} \\
-17.2\end{array}$ & -3.6 & $\begin{array}{l}5.8 \\
6.0\end{array}$ & 0.2 \\
\hline $\begin{array}{l}\text { adults (4) } \\
\text { zoeae (1) }\end{array}$ & $\begin{array}{l}-16.3 \pm 1.7^{\mathrm{a}} \\
-15.9\end{array}$ & $.7^{\mathrm{a}} \quad 0.4$ & $\begin{array}{l}5.6 \pm 1.1 \\
4.6\end{array}$ & -1.0 \\
\hline
\end{tabular}

Recently hatched zoeae were generally depleted in the heavier isotope compared to parental adults (Table 3 ). Larval tissue was ${ }^{13} \mathrm{C}$-depleted by up to $3.8 \%$ and ${ }^{15} \mathrm{~N}$-depleted by up to $2.3 \%$ (Table 3 ). Only 2 small positive shifts (larvae enriched in the heavier isotope within the magnitude of measurement precision) were observed. The observed ${ }^{13} \mathrm{C}$-depletion could be partially explained by differences in $\mathrm{C} / \mathrm{N}$ ratios (and thus in lipid content) between zoeae and adults. The $\mathrm{C} / \mathrm{N}$ ratios of recently hatched zoeae $(4.4 \pm$ 0.3 ) were always higher than the $\mathrm{C} / \mathrm{N}$ ratios of adult tissue $(3.6 \pm 0.1)$, indicating higher lipid content in zoeal tissue. However, even after 'lipidnormalising' the $\delta^{13} \mathrm{C}$ values (McConnaughey \& McRoy 1979), our results still suggest that zoeae were ${ }^{13} \mathrm{C}$ depleted in comparison to parental tissue.

\section{Macrofauna}

Mangrove oysters Crassostrea rhizophorae were the most ${ }^{13} \mathrm{C}$-depleted organisms among the estuarine macrofauna analysed (Table 2). Oyster tissue was ${ }^{13} \mathrm{C}$-enriched by only $1.7 \%$ in relation to estuarine POM. Adults of the penaeid shrimp species Litopenaeus schmitti and Farfantepenaeus subtilis were ${ }^{13} \mathrm{C}$-enriched by 7.1 and $8.6 \%$, respectively, in relation to mangrove carbon. The $\delta^{13} \mathrm{C}$ values measured for adult shrimp were within the range of values measured for penaeid postlarvae (Table 2). Accordingly, insertion of these values into our mixing equation showed that mangrove carbon did not contribute to the nutrition of adults of these shrimp species either (Table 2). The same is true for the estuarine sardine Opisthonema oglinum.

Although mangrove carbon was abundant in the water column and in estuarine sediments, only estuarine copepods, oysters, and porcellanid zoeae displayed $\delta^{13} \mathrm{C}$ values that indicated considerable contributions of mangrove carbon to their nutrition (Table 2). 


\section{DISCUSSION}

The relative constancy observed in mangrove leaf $\delta^{13} \mathrm{C}$ shows that there is little change in $\delta^{13} \mathrm{C}$ during leaf senescence and estuarine drift, and confirms that mangrove carbon is well represented by the $\delta^{13} \mathrm{C}$ value for floating mangrove leaves $(-26.8 \pm 0.4 \%$ o) used in our mixing equation. Our $\delta^{13} \mathrm{C}$ values for estuarine POM suggest mangrove carbon contributions to the water column that are higher than those reported for Malaysian and Australian mangrove estuaries (Rodelli et al. 1984, Newell et al. 1995, Loneragan et al. 1997) but are comparable to POM ${ }^{13} \mathrm{C}$ values reported from mangrove areas in Southeast Brazil (Rezende et al. 1990) and South Florida (Harrigan et al. 1989). Our $\delta^{13} \mathrm{C}$ data support the concept of mangrove forests as important sources of suspended particulate organic matter and coarse detritus at the Itamaracá estuary. In our study area, organic carbon exported from mangrove forests to the estuary was not detected on the adjacent continental shelf (Schwamborn et al. 1999b, this study). This was evident in a maximum in $\delta^{13} \mathrm{C}$ in POM and zooplankton samples. Retention of POM in the Itamaracá estuary is probably due to low freshwater runoff and the barrier formed by sandstone reefs.

In spite of the dominance of mangrove carbon in the water column and estuarine sediments, most decapod crustacean larvae showed $\delta^{13} \mathrm{C}$ values that are typical for food webs based on microalgae. Brachyuran larvae have been shown to feed directly on phytoplankton (Meyer-Harms \& Harms 1993). However, it is more likely that a mixture of phytoplankton and zooplankton are the main food source for decapod larvae in the study area.

Postlarvae of Litopenaeus schmitti caught far inside the estuary were not ${ }^{13} \mathrm{C}$-depleted (i.e. not more similar to mangrove carbon) compared to $L$. schmitti postlarvae caught in the inlets. This would be expected if there was a shift from phytoplankton- to mangrovebased sources in postlarval nutrition during immigration into the estuary. In contrast, individuals from the inner estuary were even slightly ${ }^{13} \mathrm{C}$-enriched. This indicates that the overall high $\delta^{13} \mathrm{C}$ values observed for L. schmitti postlarvae are due to avoidance of mangrove detritus while feeding inside the estuary. This is in accordance with experimental evidence for the inappropriateness of vascular plant detritus to promote growth in postlarval penaeid shrimp (Gleason 1986). Copepods have been reported to be an important prey of penaeid shrimp postlarvae and early juveniles (Briones 1988, Stoner \& Zimmerman 1988). Still, there was a ${ }^{13} \mathrm{C}$-difference of more than $3 \%$ between copepods and shrimp postlarvae in our study area; this is much larger than any ${ }^{13} \mathrm{C}$-fractionation values reported for appropriately fed penaeid postlarvae (Fry \& Arnold
1982, Gleason 1986, Dittel et al. 1997). Therefore, other ${ }^{13} \mathrm{C}$-rich sources, such as benthic diatoms, large centric diatoms (Coscinodiscus centralis), and/or other zooplankton organisms (e.g. brachyuran zoeae, rotifers, tintinnids, cirripedian nauplii, etc.) may have been utilised additionally.

Decapod postlarvae were more than $2.4 \%{ }^{15} \mathrm{~N}$ enriched in relation to estuarine POM. These relatively high $\delta^{15} \mathrm{~N}$-values hint at a mixed (herbivorous and carnivorous) or carnivorous diet. The nutritional importance of an animal diet for decapod larvae has been proved extensively in laboratory and field experiments (Dittel et al. 1997).

Our results suggest that estuarine copepods (dominated by Acartia lilljeborgi) ingest measurable amounts of mangrove carbon in the study area (Table 2). These estuarine copepods may not feed directly on mangrove leaf detritus, but on microzooplankton food webs based on mangrove carbon. Detritus ingestion by calanoid copepods has been documented by several authors, although microalgae are generally preferred over detritus (Roman 1984, DeMott 1988). In our study area, mangrove carbon contributed only 13 to $40 \%$ to copepod nutrition, while this carbon source dominated the organic carbon in the water column, thus supporting the idea of selective feeding on other carbon sources. The idea that mangrove carbon is ingested by estuarine copepods is not new (Odum 1971). Stoner and Zimmerman (1988) presented ${ }^{13} \mathrm{C}$ values for Acartia tonsa in a Puerto Rican mangrove estuary, that produce a 49 to $100 \%$ mangrove carbon contribution to the tissue of these copepods.

The assimilatory shifts found in this study are within the values assumed in our mixing equation, and within the range of values reported in other studies (DeNiro \& Epstein 1978, Teeri \& Schoeller 1979, Gleason 1986, Dittel et al. 1997, Fantle et al. 1999). The fast change in stable isotope ratios $\left(\delta^{13} \mathrm{C}\right.$ and $\left.\delta^{15} \mathrm{~N}\right)$ observed immediately after hatching agrees with results of other studies on fast-growing larval organisms (Fry \& Arnold 1982, Frazer at al. 1997). A recent study on the turnover rates of larvae of Petrolisthes armatus (Schwamborn et al. unpubl. data) showed that the half time of larval tissue was only $2 \mathrm{~d}$ for carbon and nitrogen. Also, it was shown that even $12 \mathrm{~d}$ after hatching, approximately $5 \%$ of the larval tissue was still derived from the initial embryonic tissue. This shows that, in addition to other factors which must be considered (biochemical composition of larvae and food, ingestion, growth and respiration rates, etc.), the initial isotope value has a small, but significant effect on larval stable isotope values and thus on the fractionation values obtained in laboratory feeding experiments.

The determination of the embryonic shift in the present study should be viewed as a preliminary assess- 
ment of the order of magnitude and variation of this hitherto undescribed phenomenon, since only a few species were considered and only a few samples per species were measured for this purpose. However, it has made clear that there are considerable differences between parental and larval tissue, and that the shift during embryogenesis is generally towards a depletion in the heavy isotope. It has also shown that the scale of this embryonic shift can be even larger (e.g. up to $3.8 \%$ ${ }^{13} \mathrm{C}$-depletion) than the scale reported for metabolic shifts that occur during feeding and growth (Dittel et al. 1997, Fantle et al. 1999, present study). A difference in lipid content was suggested by the higher $\mathrm{C} / \mathrm{N}$ ratios in the larval tissue, which could partially explain the ${ }^{13} \mathrm{C}$-depletion of larvae compared to parental tissue. However, 'lipid-normalisation' of these $\delta^{13} \mathrm{C}$-data showed that the difference in $\mathrm{C} / \mathrm{N}$ ratio was not sufficient to explain these large isotope shifts. Also, there is a considerable range of variation, from zero or slightly positive towards extremely negative shifts. These preliminary results have demonstrated the need for investigation on the processes that regulate fractionation during crustacean embryogenesis.

Interpretation of $\delta^{13} \mathrm{C}$ values of field-collected early zoeal stages is difficult, since absolute age and feeding history are unknown. Nevertheless, these data may be used to roughly assess the dominant carbon sources present in the tissue of these organisms, which constitute an important fraction of estuarine zooplankton. In the study area, early stages of brachyuran and porcellanid zoeae account for more than $80 \%$ of the meroplankton in the size fraction greater than $300 \mu \mathrm{m}$ (Schwamborn 1997). Porcellanid zoeae (dominated by Petrolisthes armatus) were the only decapod crustaceans to display relatively low $\delta^{13} \mathrm{C}$ values that could be related to an important contribution of mangrove carbon to their tissue carbon. However, these low values may also be due to the negative shift that occurs during embryogenesis, as shown in the present study. This shift may produce the $\delta^{13} \mathrm{C}$ value for porcellanid zoeae observed, even when the contribution of mangrove carbon to parental populations is small or negligible. The brachyuran zoeae analysed (mainly Zoeae I of Uca spp.) showed ${ }^{13} \mathrm{C}$ values that are typical for animals that feed on microalgae. These values probably reflect the embryonic carbon derived from adult $U_{C a}$ spp. feeding on microphytobenthos communities (Currin et al. 1995, Wiedemeyer 1997).

Although only a limited sampling effort was invested in the aquatic macrofauna, our study shows that shrimps and sardines displayed generally low percentages of assimilated mangrove carbon. Mangrove oysters appear to feed non-selectively and assimilate considerable amounts of mangrove carbon. Microalgae were probably the main primary carbon source for adult shrimps in the Itamaracá estuarine system. This is in accordance with $\delta^{13} \mathrm{C}$ measurements of most shrimp species in mangrove areas (Rodelli et al. 1984, Stoner \& Zimmerman 1988). Conversely, the use of mixing equations produced much higher mangrove contributions for shrimp in Australian mangroves (Loneragan et al. 1997) than in the present study. There, up to $65 \%$ of shrimp tissue was derived from mangrove carbon (mangrove leaves and seston as endmembers of the mixing equation). In agreement with our results, recent stomach-content studies suggest that the direct contribution of vascular plant detritus to penaeid shrimp nutrition is negligible (see Schwamborn \& Criales 2000 and references therein). The $\delta^{13} \mathrm{C}$ values of estuarine sardines are in agreement with the planktivorous behaviour expected. The $\delta^{13} \mathrm{C}$ values of POM and mangrove oysters showed a difference of $1.7 \%$, supporting the idea of a positive assimilatory isotopic shift of this magnitude.

The present study presents first results of in situ assessment of the importance of mangrove carbon to tropical estuarine decapod larvae. It provides further evidence that detritus exported from mangrove forests is not as important for pelagic food webs as expected in earlier studies (Odum 1971, Odum \& Heald 1972). Still, these unique ecosystems are the essential habitat of several invertebrate species, which produce planktonic larvae that may dominate estuarine and marine mesozooplankton communities (Schwamborn et al. 1999a). In areas where a massive production of invertebrate larvae occurs, larval release and dispersal seems to be one of the main pathways of energy transfer from mangrove ecosystems to estuarine and marine pelagic food webs.

Acknowledgements. Thanks to G. Hempel, K. Anger, C. von Dorrien, S. Neumann-Leitão, and B. Knoppers for support and helpful comments. The authors thank P. A. Coelho and P. A. Coelho Jr. for the identification of the ovigerous females. M. Segl contributed with a part of the carbon isotope measurements. W. L. Wiedemeyer co-operated during field work and provided a mixture of mangrove leaves used in this study. Thanks to all colleagues at Departamento Oceanografia, Universidade Federal de Pernambuco for local support and comments. This study was supported by the German Federal Minister for Education, Science, Research and Technology (project number $0339607 \mathrm{~A}$ ). We thank the 3 anonymous referees who contributed to the improvement of the initial manuscript.

\section{LITERATURE CITED}

Briones EE (1988) Variación en la dieta de postlarvas y juveniles de camarón en observación de campo. Acuavision (Fondepesca, Mex) 3(14):27-28

Coelho PA, Ramos-Porto M (1995) Distribuição ecológica dos crustáceos decápodos marinhos do Nordeste do Brasil. Trab Oceanogr Univ Fed Pernamb 23:113-127 
Craig H (1957) Isotopic standards for carbon and oxygen and correction factors for mass spectrometric analysis of carbon dioxide. Geochim Cosmochim Acta 12:133-149

Currin CA, Newell SY, Paerl HW (1995) The role of standing dead Spartina alterniflora and benthic microalgae in salt marsh food webs: considerations based on multiple stable isotope analysis. Mar Ecol Prog Ser 121:99-116

DeMott WR (1988) Discrimination between algae and detritus by freshwater and marine zooplankton. Bull Mar Sci 43: 486-499

DeNiro MJ, Epstein S (1978) Influence of diet on the distribution of carbon isotopes in animals. Geochim Cosmochim Acta 42:495-506

Dittel AI, Epifanio CE, Cifuentes LA, Kirchman DL (1997) Carbon and nitrogen sources for shrimp postlarvae fed natural diets from a tropical mangrove system. Estuar Coast Shelf Sci 45:629-637

Dittel AI, Epifanio CE, Schwalm SM, Fantle MS, Fogel ML (2000) Carbon and nitrogen sources for juvenile blue crabs Callinectes sapidus in coastal wetlands. Mar Ecol Prog Ser 194:103-112

Fantle MS, Dittel AI, Schwalm SM, Epifanio CE, Fogel ML (1999) A food web analysis of the juvenile blue crab, Callinectes sapidus, using stable isotopes in whole animals and individual amino acids. Oecologia 120:416-426

Frazer TK, Ross RM, Quetin, LB, Montoya, JP (1997) Turnover of carbon and nitrogen during growth of larval krill, Euphausia superba Dana: a stable isotope approach. J Exp Mar Biol Ecol 212:259-275

Fry B, Arnold GP (1982) Rapid ${ }^{13} \mathrm{C} /{ }^{12} \mathrm{C}$ turnover during growth of brown shrimp (Penaeus aztecus). Oecologia 54: 200-204

Gleason DF (1986) Utilization of salt marsh plants by postlarval brown shrimp: carbon assimilation rates and food preferences. Mar Ecol Prog Ser 31:151-158

Gorokhova E, Hansson S (1999) An experimental study on variations in stable carbon and nitrogen isotope fractionation during growth of Mysia mixta and Neomysis integer. Can J Fish Aquat Sci 56:2203-2210

Harms J (1992) Effects of nutrition (herbivore vs carnivore) on energy charge and nucleotide composition in Hyas araneus larvae. Helgol Meeresunters 46:29-44

Harms J, Seeger B (1989) Larval development and survival in seven decapod species (Crustacea) in relation to laboratory diet. J Exp Mar Biol Ecol 133:129-139

Harms J, Anger K, Klaus S, Seeger B (1991) Nutritional effects on ingestion rate, digestive enzyme activity, growth, and biochemical composition of Hyas araneus L. (Decapoda: Majidae) larvae. J Exp Mar Biol Ecol 145:233-265

Harms J, Meyer-Harms B, Dawirs RR, Anger K (1994) Growth and physiology of Carcinus maenas (Decapoda, Portunidae) larvae in the field and in laboratory experiments. Mar Ecol Prog Ser 108:107-118

Harrigan P, Zieman JC, Macko SA (1989) The base of nutritional support for the gray snapper (Lutjanus griseus): an evaluation based on a combined stomach content and stable isotope analysis. Bull Mar Sci 44:65-77

Kempf M, Mabesoone JM, Tinoco IM (1970) Estudo da plataforma continental na área do Recife (Brasil) I. Generalidades sobre o fundo. Trab Oceanogr Univ Fed Pernamb 9: 125-148

Lee SY (1995) Mangrove outwelling: a review. Hydrobiologia 295:203-212

Lee SY (1999) Tropical mangrove ecology: physical and biotic factors influencing ecosystem structure and function. Aust J Ecol 24:355-366

Lee WY, Omori M, Peck RW (1992) Growth, reproduction and feeding behaviour of the planktonic shrimp, Lucifer faxoni Borradaile, off the Texas coast. J Plankton Res 14:61-69

Loneragan NR, Bunn SE, Kellaway DM (1997) Are mangroves and seagrasses sources of organic carbon for penaeid prawns in a tropical Australian estuary? A multiple stableisotope study. Mar Biol 130:289-300

Mariotti A (1983) Atmospheric nitrogen is a reliable standard for natural ${ }^{15} \mathrm{~N}$ abundance measurements. Nature 303:685

McConaugha JR (1985) Nutrition and larval growth. In: Wenner AM (ed) Crustacean issues. 2: Larval growth. AA Balkema, Rotterdam, p 127-159

McConnaughey T, McRoy CP (1979) Food-web structure and the fractionation of carbon isotopes in the Bering Sea. Mar Biol 53:257-262

McKinnon AD, Klumpp DW (1998) Mangrove zooplankton of North Queensland, Australia. II. Copepod egg production and diet. Hydrobiologia 362:145-160

Medeiros CQ, Kjerfve B (1993) Hydrology of a tropical estuarine system: Itamaracá, Brazil. Estuar Coast Shelf Sci 36: 495-515

Meyer-Harms B, Harms J (1993) Detection of phytoplankton pigments by HPLC in Hyas araneus larvae (Crustacea: Decapoda): comparison of field and laboratory samples. Neth J Sea Res 31:153-161

Morgan SG (1990) Impact of planktivorous fishes on dispersal, hatching, and morphology of estuarine crab larvae. Ecology 71:1639-1652

Newell RIE, Marshall N, Sasekumar A (1995) Relative importance of benthic microalgae, phytoplankton, and mangroves as sources of nutrition for penaeid prawns and other coastal invertebrates from Malaysia. Mar Biol 123:595-606

Odum WE (1971) Pathways of energy flow in a South Florida estuary. Univ Miami Program Sea Grant Tech Bull 7:1-162

Odum WE, Heald EJ (1972) Trophic analysis of an estuarine mangrove community. Bull Mar Sci 22:671-738

Posch T, Arndt H (1996) Uptake of submicrometre-sized and micrometre-sized detrital particles by bacterivorous and omnivorous ciliates. Aquat Microb Ecol 10:45-53

Rezende CE, Lacerda LD, Ovalle ARC, Silva CAR, Martinelli LA (1990) Nature of POC transport in a mangrove ecosystem: a carbon isotopic study. Estuar Coast Shelf Sci 30: 641-645

Robertson AI (1991) Plant-animal interactions and the structure and function of mangrove forest ecosystems. Aust J Ecol 16:433-443

Robertson AI, Blaber SJM (1992) Plankton, epibenthos, and fish communities. In: Robertson AI, Alongi DM (eds) Tropical mangrove ecosystems. American Geophysical Union, New York, p 173-224

Robertson AI, Dixon P, Daniel PA (1988) Zooplankton dynamics in mangrove and other nearshore habitats in tropical Australia. Mar Ecol Prog Ser 43:139-150

Robertson AI, Alongi DM, Boto KG (1992) Food chains and carbon fluxes. In: Robertson AI, Alongi DM (eds) Tropical mangrove ecosystems. American Geophysical Union, New York, p 293-326

Rodelli MR, Gearing JN, Gearing PJ, Marshall N, Sasekumar A (1984) Stable isotope ratio as a tracer of mangrove carbon in Malaysian ecosystems. Oecologia 61:326-333

Roman MR (1984) Utilization of detritus by the copepod, Acartia tonsa. Limnol Ocenogr 29:949-959

Roman MR, Rublee PA (1981) A method to determine in situ zooplankton grazing rates on natural particle assemblages. Mar Biol 65:303-309

Schwamborn R (1997) Influence of mangroves on community structure and nutrition of macrozooplankton in Northeast Brazil. PhD thesis, Bremen University, Germany 
Schwamborn R, Bonecker ACT (1996) Seasonal changes in the transport and distribution of meroplankton into a Brazilian estuary with emphasis on the importance of floating mangrove leaves. Braz Arch Biol Technol 39: $451-462$

Schwamborn R, Criales MM (2000) Feeding strategy and daily ration of juvenile pink shrimp (Farfantepenaeus duorarum) in a South Florida seagrass bed. Mar Biol 137: 139-147

Schwamborn R, Saint-Paul U (1996) Mangroves_forgotten forests? Nat Resour Dev 43/44:13-36

Schwamborn R, Ekau W, Silva AP, Silva TA, Saint-Paul U (1999a) The contribution of estuarine decapod larvae to marine zooplankton communities in North-East Brazil. Arch Fish Mar Res 47:167-182

Schwamborn R, Ekau W, Voss M, Saint-Paul U (1999b) Stable isotope composition of particulate organic matter and zooplankton in northeast Brazilian shelf waters. Arch Fish Mar Res 47:201-210

Stoner AW, Zimmerman RJ (1988) Food pathways associated with penaeid shrimps in a mangrove-fringed estuary. Fish Bull 86:543-551

Teeri JA, Schoeller DA (1979) $\delta^{13} \mathrm{C}$ values of an herbivore and

Editorial responsibility: Otto Kinne (Editor),

Oldendorf/Luhe, Germany the ratio of $\mathrm{C} 3$ to $\mathrm{C} 4$ plant carbon in its diet. Oecologia 39: $197-200$

Wehrtmann IS, Dittel AI (1990) Utilization of floating mangrove leaves as a transport mechanism of estuarine organisms, with emphasis on the decapod Crustacea. Mar Ecol Prog Ser 60:67-73

Welch JE, Epifanio CE (1995) Effect of variations in prey abundance on growth and development of crab larvae reared in the laboratory and in large field-deployed enclosures. Mar Ecol Prog Ser 116:55-64

Wiedemeyer W (1997) Analysis of the benthic food web of a mangrove food web of a mangrove ecosystem at northeastern Brazil. PhD thesis, Kiel University, Germany

Wolff M, Koch V, Chavarria JB, Vargas JA (1998) A trophic flow model of the Golfo de Nicoya, Costa Rica. Rev Biol Trop 46:63-79

Wolff M, Koch V, Isaac V (2000) A trophic flow model of the Caeté Mangrove Estuary (North Brazil) with considerations for the sustainable use of its resources. Estuar Coast Shelf Sci 50:789-803

Zar J (1996) Biostatistical analysis, 3rd edn. Prentice-Hall, Upper Saddle River, NJ

Submitted: January 12, 2001, Accepted: July 20, 2001

Proofs received from author(s): February 14, 2002 